\title{
Regional Library Centers Today: A Symposium
}

$T^{\text {HE }}$ A.L.A. Bibliography Committee decided early in 1946, after surveying its field 1 of interest, to concentrate on gathering and dispensing information about bibliographic centers and union catalogs. Upon learning that Ralph T. Esterquest, director of the Pacific Northwest Bibliographic Center, planned a meeting at Buffalo of the heads of regional library centers, the committee obtained his permission to sponsor his closed meeting and widen its scope by changing it into two open meetings on the administration of regional library centers and the problems the centers attempt to solve. Since other committees share an interest in the subject, the Bibliography Committee asked the Board on Resources of American Libraries and the Division of Cataloging and Classification to co-sponsor the programs and to help Mr. Esterquest and the Bibliography Committee plan the meetings, to be called an Institute on Regional Library Centers. The following papers, abridged to meet the space requirements of College and Research Libraries, were planned to give an accurate picture of bibliographic centers and union catalogs today.

Regional library centers are a fairly recent manifestation of the trend among American libraries toward placing the printed and staff resources of many libraries at the disposal of the clients of each library. In the thirties and early forties foundation grants and W.P.A. labor enabled groups of libraries to compile regional union catalogs. Some of these catalogs now have a staff only large enough to keep the catalog up to date. Others, with a larger staff, provide various kinds of bibliographic assistance to the contributing libraries. With the end of the war, interest in regional library centers has revived. The need for cooperation among neighboring libraries was demonstrated during the war. In the period of library expansion which lies ahead, plans for additional centers will probably materialize and the present centers will develop new functions. To assist planners, the proceedings which follow were made as factual as possible. They supplement, and interpret in the light of experience, the basic facts on costs and methods to be found in R. B. Downs, Union Catalogs in the United States.-John VanMale, assistant director of libraries, University of Denver.

\section{The Pacific Northwest Bibliographic Center}

\section{Administration and Organization}

When, in 1940, the Pacific Northwest Library Association received a grant of $\$ 35,000$ from the Carnegie Corporation for the establishment of a bibliographic center, it placed the responsibility for its expenditure upon the association's Committee on Bibliography. During the period 1940 to 1944 , this com- mittee watched over the birth of the union catalog, employed John VanMale to survey the resources of Pacific Northwest libraries, and supervised the inauguration of the center's first services. Not authorized to settle such fundamental questions as: Shall a bibliographic center be continued after the Carnegie grant is exhausted? And how might it be continued without foundation support? the 
committee turned the problem of the future of the center over to the association at large. At the Spokane conference in June $\mathrm{I} 944$ the P.N.L.A. voted unanimously in favor of continuing the center and instructed its incoming board of directors to devise ways and means for so doing.

Five months later, the P.N.L.A. Board of Directors had adopted a plan for the financial support of the bibliographic center, whereupon it authorized the Committee on Bibliography to administer the plan and to continue on a permanent basis the administration of the center. This action gave the Pacific Northwest Bibliographic Center its constitutional authority and defined its present organizational.setup.

The P.N.L.A. membership elects a board of directors, the board appoints a Committee on Bibliography, the committee formulates policy and hires a director. The director and his staff carry out the instructions of the committee and perform the services of the center. The director reports monthly to the committee; the committee reports annually to the P.N.L.A. The Committee on Bibliography consists of five members, one from each state and province in the association. An attempt has been made to keep the committee representative of types of libraries; at present two members are public librarians, three are university librarians. The chairman has for many years been the librarian of the University of Washington, in whose building the bibliographic center is located.

The bibliographic center staff is composed of two trained librarians, the director and the union catalog editor, and the equivalent of four untrained assistants. The director administers the center and performs many of the actual services. The union catalog editor has the full responsibility of the union catalog, supervising the filers and performing the necessary research tasks to reconcile varying entries. A full-time and half-time filer alphabet and file the new cards that are added at the rate of about 210,000 a year. Another full-time and another half-time worker are engaged in adding titles to the catalog from the negative sheets representing library catalogs photographed during the W.P.A. days. The final member of the staff is the full-time secretary.

No report on the organization of the Pacific
Northwest Bibliographic Center can afford to omit the important element of its close tie-up with the Pacific Northwest Library Association. To induce librarians to use and to support a bibliographic center takes much coaxing, publicity, and educating. Fortunately, the P.N.L.A. has to a considerable extent done this. A long history of regional cooperation in library matters has created a receptive atmosphere. Beginning with volume one, number one, the P.N.L.A. Quarterly has carried papers and reports on bibliographic center plans. When the center was finally established, therefore, librarians in the region were ready to test its services. And when the time came to support the center, enough Pacific Northwest libraries had used it to be sold on its claim for existence. Today, a librarian who is a member of the P.N.J.A. regularly reads about his center in the Quarterly, where a "News from the Bibliographic Center" feature appears every issue.

\section{Finance}

When the P.N.L.A. Board of Directors met to formulate a plan for the center's financial support in November 1944 it agreed upon a number of fundamental principles. One of them might be stated this way: because the developing services of the center are presumed to extend to all libraries in the region-large and small, university, public, and special-the cost of such services should be shared equitably by all libraries, probably in accordance with ability to pay. Suggestions were made that support might be derived by applying a scale of fees tor specific services, thus asking the libraries to pay only for value received. The prevailing opinion, however, rejected all such proposals on the ground that if applied to the center's inaugural servicethat of arranging interlibrary loans-it would place the burden on those libraries least able to pay and would quickly discourage use. In the end, the library's annual income was finally adopted as the proper measure of its ability to pay.

The next step was to derive a formula to be applied against library incomes. Available directories listed some 225 libraries in the Pacific Northwest, with a total combined annual income of $\$ 2,922,000$. However, the list included IIo whose incomes were less than $\$ 5,000$ per year. It was obvious that such 
small, often part-time, libraries could not afford to pay anything. A realistic plan would necessarily omit them. The remaining II5 libraries were grouped as follows:

\begin{tabular}{|c|c|c|}
\hline State & $\begin{array}{c}\text { Number of } \\
\text { Libraries }\end{array}$ & $\begin{array}{c}\text { Total Income of } \\
\text { All Libraries in } \\
\text { Group }\end{array}$ \\
\hline Washington & 35 & $\$ 1,11$ I, 000 \\
\hline Oregon & 35 & $1,020,000$ \\
\hline British Columbia & 10 & 316,000 \\
\hline Montana & 24 & 242,000 \\
\hline Idaho & II & 143,000 \\
\hline Total & 115 & $\$ 2,836,000$ \\
\hline
\end{tabular}

It was seen that the center's budget of $\$ 7,000$ was one-fourth of I per cent of this $\$ 2,836,000$. But the response to an earlier trial balloon, and correspondence with many librarians, had shown that a simple pro rata assessment such as this had these principal defects :

I. It did not take into account variations in need for the various services of the center.

2. It did not allow for the difference between college library and public library budgets: one group paid janitor and building costs, the other did not.

3. It assumed that all 115 libraries in the group would cooperate in paying their assessments in full.

4. It assumed that libraries of different sizes could equally afford to pay the same percentage out of their incomes.

Adjustments were made, therefore, and the plan adopted attempted to reconcile two somewhat opposing ideals: it should take into account all relevant factors and compensate for variations in "need" and "ability to pay," but at the same time it should remain reasonably simple and understandable to the librarians who would be asked to pay. The finance plan ultimately adopted divided the libraries of the Northwest into three groups:

I. Libraries with annual incomes in excess of $\$ 25,000$ : Each college and university library is asked to contribute three-tenths of I per cent of its income. Each public library is asked to contribute three-tenths of I per cent of its income less 20 per cent, to compensate for the building maintenance factor.

2. Libraries with annual incomes between
$\$ 5,000$ and $\$ 25,000$ : Each is asked to contribute according to the following scale:

$\begin{array}{ccc}\text { Public } & \begin{array}{c}\text { College, Univer- } \\ \text { sity , and Special } \\ \text { Income }\end{array} & \begin{array}{c}\text { Libraries } \\ \text { Libraries }\end{array} \\ \$ 5,000 \text { to } \$ 10,000 & \$ 20 & \$ 25 \\ 10,001 \text { to } 15,000 & 25 & 30 \\ 15,001 \text { to } 20,000 & 30 & 35 \\ 20,001 \text { to } 25,000 & 35 & 40\end{array}$

3. Libraries with annual incomes of less than $\$ 5,000$ : No library in this group is asked for a specific contribution, but nominal contributions are accepted.

This plan was put into operation on Jan. I, 1945. The receipts during the first year exceeded anticipation. Although the center budget called for $\$ 7,000, \$ 7,500$ was subscribed by $13 \mathrm{I}$ libraries. It is of particular interest to note that the 131 libraries included 28 of the low-income group which gave tangible proof of their support by sending checks of from $\$ 5$ to $\$ 30$. Income this year will be about $\$ 800$ over last year, due to increased budgets in many of the contributing libraries.

The center's budget of expenditures is very simple. Of the $\$ 8,000$ to be spent during 1946, most will go for salaries. Postage, stationery, and supplies require about $\$ 200$. Promotional activities and travel, another $\$ 200$. No money is spent for housing, heat, light, desks, and typewriters. These items are furnished by the University of Washington Library.

\section{Services}

At present we spend most of our time on maintaining the union catalog and on interlibrary loans. Maintaining the catalog is not a service; only the use we make of it can be so defined. The interlibrary loan service does, however, represent a-tangible good delivered to patron libraries. Any library in the Pacific Northwest region may request a specific book or books from the center. Once requested, the librarian can forget about it until it is delivered. The center locates a copy either through its own union catalog or through consulting other bibliographic centers and union catalogs. When it locates the needed item, the center requests the owning library to send it on interlibrary loan to the library which needs it. The center takes care of all the correspondence with owning 
libraries which leads up to a successful loan transaction. Once the book is sent on its way, however, the transaction becomes a relationship between the owning and the borrowing library.

Before we leave this subject, the basic Regional Interlibrary Loan Code should be mentioned. When the union catalog was ready to function in 1942 , most of the libraries in the Pacific Northwest signed the following code:

\section{Proposed Regional Interlibrary Loan Code}

As an expression of the view that each library holds its books in trust for the region as a whole, the libraries of the Pacific Northwest lend each other books for all kinds and conditions of clients, for any purpose, and for any length of time, within reason. It is understood, however, that each library reserves the right to decide whether to lend a given book for the purpose and the length of time requested. The borrowing library assumes responsibility for the safe return of the book and pays transportation charges both ways. This regional code applies only within the region (Montana, Idaho, Oregon, Washington, and British Columbia). Loans to and from libraries outside the region are regulated by the national code.

This code has opened the bookstacks of Northwest libraries to readers everywhere in the region. We like to think of it as putting into practice what A.L.A. President Ulveling has called "cooperation at the operational level." During the early months of 1946 the center has arranged loans at an average of 625 a month. Last year, some 3300 specific books were requested and supplied. About I 25 libraries are regular users of the service.

Last year a new service was inaugurated: a regional plan for systematic discarding. Of some 14,000 volumes discarded by seven of the larger public libraries of the region during a three-year period, 3500 were titles of which no other copy was listed in the union catalog as existing in Pacific Northwest libraries. Fifty libraries have divided up the subject fields of the Dewey classification and have agreed to accept and preserve regional "last copies" discarded by other libraries. The mechanics are simple. A library planning to discard a group of books sends a list to the center. The list is checked against the union catalog. Those items which are held by other libraries-are so indicated and the discarding library is free to pulp them. Those titles that appear to be unique in the discarding library are preserved for the region by being sent to one of the designated repositories, determined according to the subject of the book.

To help coordinate the acquisition of material, the center checks buying lists sent in by smaller libraries. The union catalog often shows that copies of books for which purchase is contemplated are available in other libraries nearby. Skeptical library boards can often be convinced of the value of the bibliographic center on the strength of this service alone, and the book resources of the region as a whole are enriched when book funds are not spent for duplicate copies of expensive, littleused items. The center has recently set up a central file giving information on subject bibliographies and reading lists compiled by libraries in the region. When a homemade bibliography is made, the compiling library sends to the center a copy or a card description. This service is intended to help librarians avoid duplication of effort in the time-consuming job of compiling bibliographies on subjects of current popularity. A joint-purchase agreement, on which the Denver and the Seattle centers have collaborated, brings maximum discounts on book purchases to participating libraries. In the Northwest, I I0 libraries are enrolled.

Other services fade in relative importance, however, when compared with the potentialities of the subject specialization program. Library specialization has been a topic of discussion in library circles for years. In November 1943 the principal librarians of the Pacific Northwest answered a call for a conference on regional specialization which was held in the quarters of their bibliographic center. $^{1}$ Specialization in the Northwest has gone forward since then. Libraries submit an annual report to the center on progress made in building in established fields and the establishment of new fields. The center assists by helping to enumerate and define fields of specialization, by encouraging the establishment of new fields, and by giving publicity regarding what libraries are assuming responsibility for what fields. An innovation has been the extension of the specialization idea to the medium-sized and small libraries.

1 The proceedings of this conference were published in the January 1944 P.N.L.A. Quarterly. 
Some of these have selected narrow subject fields, usually having a local interest, and are concentrating on them. A public library in Idaho, for example, is building a collection on the potato-growing industry and has received the assurance of financial backing from local businessmen. In Pendleton, Ore., a collection on horses has been started. The time may well come when all Northwest libraries, large and small, will. look to these small institutions for specialized material in their respective fields.

The Pacific Northwest is characterized by large expanses, sparsely settled. There is little evidence that the ingredients of population concentration, wealth, and antiquity will soon produce a Harvard University Library or a New York Public Library in this territory. But subject specialization, plus a liberal interlibrary lending policy, plus systematic coordination of growth, may work together to build in the Northwest a notable collection of books, held by the several libraries jointly and readily available to them all. - Ralph $T$. Esterquest, director, Pacific Northwest Bibliographic Center.

\section{Denver's Bibliographic Center}

$\mathrm{T}$ HE Bibliographical Center for Research, Rocky Mountain Region, was founded by a group of college presidents and Malcolm G. Wyer, librarian of the Denver Public Library, in 1934. It was planned as a central collection of bibliographies. A union catalog, compiled by a W.P.A. project, changed it into the first of the "bibliographic centers," which means an agency for carrying out cooperation among libraries. The center is located in the Denver Public Library. It serves libraries in Colorado, Wyoming, Utah, New Mexico, and neighboring states.

\section{Administration}

The center is governed by representatives of the cooperating libraries, who meet once a year to decide upon general policies. This general council consists of two representatives of each "sponsor" (a library paying an assessment of $\$ 50$ or more) and three representatives elected by the "contributors" (libraries which send in less than $\$ 50$ a year). In addition to these, there is a class of individual members, who are not represented in the council. The council appoints the officers, who form an executive board, which appoints the director, who is the executive secretary of the board and administers the center. The staff of the center consists of the director, an assistant, a bibliographer, two filers, and, on occasion, members of the public library and the University of Denver Library staffs. The director and assistant, and in fact all members of the staff, work on interlibrary loans, which are handled after the fashion described by
Mr. Esterquest. The filers spend most of their time maintaining the union catalog. The bibliographer is a combined secretary and reference assistant.

\section{Finances}

This has been and still is the most pressing immediate problem. Since our bank account no longer shows a balance from gifts from the Carnegie Corporation and local foundations, we are pioneering in methods of obtaining an annual budget of $\$ 10,000$ to place our center on a firm basis. On Jan. I, 1945, we had a balance of $\$ 2388.17$, and through the year we received $\$ 6568.75$ in contributions from libraries of the Rocky Mountain Region. Receipts of 1945 included assessments paid by the principal libraries of Wyoming and Colorado, ranging from $\$ 50$ to $\$ 2250$. Other libraries, giving from $\$ 25$ to $\$ 50$, contributed $\$ 399$; still others, giving below $\$ 25, \$ 166$. Publications brought in $\$ 22$ and individuals gave $\$ 368$. Total $\$ 8956.92$. We spent $\$ 808 \mathrm{r} .92$ for salaries of five regular and five temporary workers to answer the $35,36 \mathrm{I}$ questions which were sent to the center. Miscellaneous expenses amounted to \$327.12. The funds for 1946 are coming in better than during 1945, and from January through May amounted to $\$ 4293.50$. Remaining contributions will amount to $\$ 2500$, but we need an additional $\$ 5000$ for an adequate budget.

$\mathrm{Up}_{\mathrm{p}}$ to now, we have relied mainly upon contributions from the cooperating libraries, according to a schedule worked out in 1942 by a committee on sponsors' contributions ap- 
pointed to study the problem of cost of service. On the basis of the actual use of the center by the sponsors, when the resources of the center and the intangible factor "readiness to serve" are taken into consideration, the committee recommended the following annual contributions:

Adams State Teachers College

Colorado College

Colorado School of Mines

Colorado State College of Agriculture

Colorado State College of Education

Denver Public Library

Regis College

United States Bureau of Reclamation

University of Colorado

University of Denver

University of Kansas City

University of Wyoming

Western State College

Wyoming State Library

$\$ 50.00$ 350.00

175.00

500.00

300.00

$2,000.00$

10.00

25.00

$2,000.00$

750.00

25.00

350.00

75.00

200.00

$\$ 6,810.00$

Most of the institutions paid the amounts as listed.

In March 1945 the general council asked that each sponsor increase its appropriation 25 per cent. During the past year all the institutions have willingly paid this increase.

\section{Union Catalog}

The union catalog now consists of approximately $3,600,000$ cards. Of this number, 103,847 were added during the current year, as follows: Library of Congress, 68,505 ; John Crerar, 933; revised Library of Congress, 6,362 ; location cards from union catalogs and libraries not coded, 914; cards typed, 3,500; Princeton, 1,327; anonymous and pseudonymous, $\mathrm{I}, 038$; additions from the region, $2 \mathrm{I}, 268$. The two filers file and code from five to eight hundred cards a day, in addition to helping other members of the staff. The Denver Public Library has never been coded in the union catalog, since the official catalog is located in an adjoining room, but this is now being accomplished gradually by the Denver Public Library staff as they use, the cards for cataloging. We have emphasized accuracy in compiling and maintaining our union catalog. Theodore Besterman, who came to America recently to study methods of operating bibliographical centers and anion catalogs, remarked while visiting in Denver that it "is a wonderful piece of work and carefully executed."

The Library of Congress and the Pacific Northwest Bibliographic Center use the Denver union catalog to the greatest extent. The former sent 2021 items and the latter 708 in 1945. The percentage of items located in the region for the Library of Congress was very low, but if the staff had more time to verify each request the percentage might be higher. On one occasion the present writer verified a list and found that three of the items had been entered under the wrong author entry and were actually in the Library of Congress. The items located in the Rocky Mountain Region for the Pacific Northwest Bibliographic Center numbered approximately 150. In return for the above service, the center receives excellent location information from the Library of Congress, the Pacific Northwest Bibliographic Center, and the Cleveland, Sacramento, and Philadelphia union catalogs. A system has been devised in which uniform slips are sent requesting locations of books needed in the Rocky Mountain Region. After these slips have been coded by the various catalogs and returned they are immediately filed in the Denver union catalog. Such location cards from union catalogs and libraries not already coded, numbered 914 this year. This brings into the catalog a record of books all over the United States and Canada and widens the scope for borrowing.

\section{Interlibrary Loan Service}

When a loan request comes in, the titles must often be checked with bibliographies to determine the correct author and title. Then the union catalog is checked, locations are noted, and the request for the book is made from the region if possible. Often there is no location other than the Library of Congress, in which event the request is made of a library which might logically be expected to have it. The Library of Congress is used when no other location is found or when there is not sufficient time to search for a book. Naturally, we borrow as many as we can from the Denver Public Library. In 1945, 2 Io borrowers received 1769 books from the Denver Public Library's collection.

Who uses the interlibrary loan service? Chiefly, the contributing libraries, of course. 
However, we received in 1945 nearly three thousand requests from small libraries of the Rocky Mountain Region. The questions were not difficult but required time and energy. A typical request is the following:

The head of a local bottling works is asking for help in preparing a manual for his employees, which includes the office employees, route salesmen, and the sales and production departments. He wants the results to be a manual on personal relations, working conditions, sick leave, etc. He asked specifically about prevailing practices on sick leave.

There are humorous requests, too, such as:

Autobiography of Lew Wallace. Don't know the author.

Goodbye, Mr. Chippendale.

Over ten thousand questions were sent to the center as a result of the excellent publicity received from the publication of the City Club Pamphlet No. 27, "The Bibliographical Center for Research, Rocky Mountain Region," and articles in the Christian Science Monitor and local papers. These inquiries came from 203 institutions, including Biloxi, Miss., Public Library; Ketchikan, Alaska, Public Library; and California Fruit Growers Association. Incidentally, the small nonmember libraries of the region contributed $\$ 564.50$ and these distant libraries and organizations $\$ 436$ toward the 1946 budget. In- dividuals not connected with any institution and returning soldiers wrote and came to the center to ask for help in solving 1151 questions.

The total number of items checked by the bibliographical center in 1945 was 35,361 . Of this number, 17,520 , or 49 per cent, were for the cooperating libraries; 10,956 , or 31 per cent, for the other institutions; 2,918 , or 8 per cent, for the union catalogs; 1,151 , or 3 per cent, for individuals, and 85 , or I per cent, for bookstores.

Although the location and interlibrary loan service stand out pre-eminently, we feel we have aided cooperative purchasing and cataloging, supplemented local reference work, encouraged photostatic and microfilm reproduction, and abetted the movement toward development of union catalogs throughout the United States. One of our visions for the future is to have a union catalog under subject as well as under author. We also wish to keep in touch with our sponsors by bulletin publications listing new, important holdings. Through the increasing use of our services, we are becoming an indispensable aid in freeing research workers from the limitations imposed upon them by the meager library facilities of the Rocky Mountain Region.-Eulalia Dougherty Chapman, director, Bibliographical Center for Research, Rocky Mountain Region.

\section{The Philadelphia Bibliographical Center}

$\mathrm{T}$ His marks the tenth anniversary of the union library catalog of the Philadelphia metropolitan area, which was inaugurated in 1936 and for the first few years functioned solely as a location service. In 1939 the University of Pennsylvania and the union library catalog together set up the bibliographical planning committee which investigated the entire library situation in Philadelphia, laying its emphasis upon mutual cooperation; its report was published in 1942 and is still in print. Among other things, the bibliographical planning committee recommended that the union library catalog's functions be expanded into those of a bibliographical center.

The center's governing board is called the Executive Board of the Philadelphia Biblio- graphical Center. It consists of eighteen men and women prominent in academic, library, and civic life. A fair proportion of them are drawn from the University of Pennsylvania, but other important libraries are represented, as are also leaders in civic enterprise. This board approves the yearly budget and any special expenditures that must be made, and oversees the director's work, deciding upon projects and advising with him on matters of general policy. The ownership of the funds and the properties of the center belong to the Union Library Catalogue Corporation, so that we have in Philadelphia one corporate body owning the money and plant of the center, with another unincorporated body administering the expenditures and actions of the cen- 
ter. The two controlling bodies consist to a large extent of the same persons. The executive board of the bibliographical center has an annual meeting to approve the budget and ordinarily has other meetings during the year to consider special problems as they arise.

\section{Staff}

The staff administering the affairs of the center consists at present of four persons: a director, a consultant, a secretary, and a filer. The director oversees the general policy and functioning of the center, takes care of the issuance of mimeographed or other publications, and runs the exchange service with the aid of the secretary. $\mathrm{He}$ also takes charge of the special file of bibliographies and bibliographical material which the center has collected and is responsible for the editing of the Union List of Microfilms which the center has published annually since 1942. The consultant is almost exclusively concerned with the operations of the union library catalog. Her primary duty is to service and interpret the catalog to the public. The consultant keeps the record of calls received and of action taken on them, compiles statistics monthly and annually on the volume of business. She also supervises the catalog itself to a large extent.

The secretary does a good many jobs that an ordinary secretary would not be expected to do, and indeed her work more closely resembles that of the director than anybody else. She assists in handling matters connected with the bibliographical center, does some filing, copies lists and cards, and has the somewhat difficult job of handling the actual bookkeeping of the financial accounts of the center. Since the Union Library Catalogue Corporation is a public corporation, we keep a more elaborate system of financial records than is absolutely necessary so that we may have our accounts audited yearly. She also services the catalog when necessary. Our filer is a half-time worker, yet she manages to file the seventy thousand cards we receive each year into the temporary file, to combine locations on one card whenever possible, and to transfer the cards from the temporary file into the main files.

The executive board has always had the problem of financing the center as one of its major jobs. The annual budget for the last few years has run just slightly under $\$ 9000$. Of this amount, between $\$ 5000$ and $\$ 5500$ has been raised from contributions of the libraries who use the service. Although the union library catalog contains about 160 libraries, not all can be used as a basis for calculating income. Many of these are small and inactive and never use the services. Another group of libraries contribute small amounts of only $\$ 5$ or $\$ 10$ apiece to the cata$\log$. The bulk of the contributions, then, comes from the larger and more active libraries in the vicinity, together with those industrial libraries which, though small, are active enough to use the center a good deal. An analysis of the contributions from libraries for the present year's budget shows the following distribution:

Number contributing over $\$ 500 \ldots \ldots \ldots \ldots 2_{2}$

Number contributing between $\$ 10 r-\$ 500 \ldots .8$

Number contributing between $\$ 5 x-\$ 100 \ldots . .5$

Number contributing between $\$ 11-\$ 50 \ldots .449$

Number contributing between $\$ \mathrm{r}-\$ 10 \ldots \ldots .53$

The difference between the contributions and the amount needed, some $\$ 3000$, has been met by contributions from various interested individuals.

In an effort to put the financing of the center on a firmer basis, the executive board this year decided to raise an endowment fund, to remove the necessity for depending upon special private benefactions for necessary income. We are going to conduct another campaign to meet current expenses for this year and next and also to provide, if possible, another steady source of income to bolster our running expenses in the future. This second campaign is being mapped around the idea of a "Friends of the Union Library Catalogue" organization, and we hope to interest various library and civic-minded individuals in making small annual contributions to our work.

\section{Services}

The basic service of the Philadelphia Bibliographical Center is the location service. The figures for the last nine and a half years run as follows: 


$\begin{array}{lll}1937-4,329 & 1941-34,695 & 1945-15,787 \\ 1938-10,751 & 1942-19,482 & 1946-12,000 \\ 1939-11,268 & 1943-16,263 & \text { (first 6 months) } \\ 1940-24,275 & 1944-15,156 & \end{array}$

It will be seen that the steady increase of around ten thousand inquiries a year was interrupted in 1942, but an upward swing began about last September and has continued steadily to date. The total number of items searched in 1945 was 15,787 . Of these, approximately three-fourths were searched by the staff and the rest by persons who came to the center in person. Most of the staffsearched inquiries were telephone calls. Of the total number of questions received, about 80 per cent were telephone inquiries, about 12 per cent of the total were requests for locations coming in by mail, and about 8 per cent represent material searched through personal visit.

An analysis of the inquiries for location made by source shows that about 60 per cent of the total originated in libraries. Of the remaining 40 per cent, about 16 per cent came direct"ly from teachers or students. Businessmen and organizations accounted for about 10 per cent more, and other professional men for about 3 per cent. Inquiries from other union catalogs-Denver, Seattle, and Washingtonaccount for another 3 per cent, while the remaining 8 per cent is listed in our statistics as originating from miscellaneous sources, i.e., sources which are either unidentifiable or represent calls from the general public directed to us by the public libraries in the city. In all, we located 63 per cent of the items requested in 1945 . The center has never kept a record of miscellaneous inquiries or of requests for reference service. Since it is not well equipped to answer these inquiries, it transfers them to the library best equipped to handle the question.

Since the union library catalog is a oneentry catalog, it is of course unable to afford a subject approach to materials. To provide in a measure for the subject approach and to provide the student with bibliographies and bibliographical reference material in generál, the center has compiled a special file of bibliographical and related materials. Bibliographies are, of course, the chief item in this " $Z$ File," but also included are dictionaries, encyclopedias, atlases, directories, and stand- ard reference materials. Miscellaneous information included relates to such matters as the chronological rearrangement of the ShortTitle Catalogue available at the University of Pennsylvania Library, the subject index to the same work being prepared by Professor White at Nebraska, and the Folger library's acquisition of twenty Donne manuscripts. Material for the " $Z$ File" is obtained from various sources, chief of which is the set of Library of Congress proof sheets. Publishers' Weekly is also scanned and booksellers' catalogs and library publications of all sorts are searched for material. The "Z File" carefully notes news items carrying information about specific collections in libraries or in private hands in special fields, and also collects notes about projects under way.

Another service, though relatively unimportant compared with locations and reference work, is the providing of bibliographical information regarding books. A frequent question is that asking for publisher and for publisher's -address. Much-less frequent is the question as to collation and usually when such a question comes to us, it comes from a book collector who wants to compare his copy with the standard collation. Few libraries have made any use of our vast card collection in their cataloging. In many cases the cards which appear in our files are not full enough bibliographically to be of great use to a cataloger and indeed are sometimes even unreliable, a disadvantage arising from the way in which the catalog was compiled, so that, while adequate for location purposes, the cards fail to give proper bibliographical information. Most of the accessions, however, during the last six or eight years have been in excellent bibliographical form.

The bibliographical center, through its committee on microphotography, has also published a reference work of national scope, the Union List of Microfilms. The basic list (1942), which contained about five thousand entries, has been followed by four successive annual supplements, bringing the total number of items listed in the complete work to over 16,000. A library placing an order today for the complete set will have to take the basic list and the first three supplements on film if it wants to have its order completed. The 
microphotography committee hopes that it will be able in the near future to produce a cumulation of all the items contained to date in the Union List of Microfilms in one cumulative volume, probably arranged by subject or at least provided with a subject index. In passing, it might be noted that the center possesses a card file compiled by cumulating the material received from American libraries for each successive issue of the union list. This union catalog of microfilms contains a number of locations of negatives and positives which are not to be found in the published volumes.

The last service that may be mentioned is the duplicate exchange service. In 1945, rather than dispose of a body of material which was apparently unwanted by our regular clientele, we tried the experiment of sending a special list of such items to members of the A.L.A. Duplicate Exchange Union. We have continued to send them notices of material and have been able in all to dispose usually of between 60 and 70 per cent of the material sent us for exchange.

A word or two about services which the center has offered in the past may be in order, even though they are at present not on the active list. The war documentation service during the spring of 1940 published five bulletins, of which three were bibliographical contributions to the literature of the immediate prewar and early war months. The war documentation center was an interesting experiment in cooperative cataloging. It undertook to catalog the various ephemeral material, leaflets, pamphlets, and serials, issued by various information and propaganda agencies for free distribution. Another cooperative program attempted to enable libraries to coordinate their buying to a certain extent.
Whenever an item of any importance was requested from the center and no location found in the area, that item was noted and every three months or so a list of such titles was issued for libraries to check over. It is hoped that this project may be revived shortly.

It will perhaps be noticed that I have said nothing about interlibrary loan service. This is not accidental. The center acts occasionally as the agent arranging interlibrary loans, but this is the exception rather than the rule, since most libraries in this region prefer to deal directly with the borrowing or lending library. Since this paper has dealt entirely with the affairs of the Philadelphia center, I have not attempted to indicate differences which exist between Philadelphia on the one hand and Seattle and Denver on the other. The most obvious point of variance between the eastern and western centers lies in the fact that the East has a large number of libraries in a small geographical area. The library concentration affects both the medium through which inquiries are received by the center and the services demanded and offered at Philadelphia: there is, for example, no great need for the Philadelphia Bibliographical Center to act as coordinator of interlibrary loan service for the area, since the various libraries in the vicinity can make their own arrangements as quickly and as easily as we can, once they have had the items they desire to borrow located. Other differences, though less striking, exist in the financial and administrative setups of the three centers, and a comparison of this paper with those of Mr. Esterquest and Mrs. Chapman will, I am sure, make these sometimes illuminating variations apparent.-Charles $C$. $M$ ish, director, Philadelphia Bibliographical Center.

\section{Westchester Library Association Union Catalog,}

\section{I}

IN 1942 Robert Bingham Downs's book 1 Union Catalogs in the United States so thoroughly analyzed the past of the Westchester Library Association Union Catalog that I feel impelled to speak of the present and future. Certainly this is our greatest concern. Fortunately conceived in 1939 by several intelligent and alert librarians of
Westchester County and administered subsequently by the Westchester Library Associaticn, there have been no drastic changes in financing or administration-only gradual and normal growth and expansion.

Forty-seven member libraries, including public, school, college, corporation, and county department libraries, contribute 2 per cent 
of their individual book funds, theoretically, to the general budget. Membership dues in the W.L.A., subscriptions to the News Letter, and the paid advertising therein, give W.L.A. about $\$ 2200$ to support the union catalog and other smaller activities of the association. This is administered by an executive board which is composed of the officers, chairmen of standing committees, past president, and librarian. The standards committee, made up of seven librarians from various corners of the county, directly administer the union catalog with the help of the librarian. C. C. Williamson, late of Columbia, has given W.L.A., as a permanent loan, his set of $A$ Catalog of Books Represented by Library of Congress Printed Cards. With this and CBI's, the Union List of Serials, the bibliographic and other indexes, and our catalog of five hundred thousand authors of books, pamphlets, continuations, and magazines, the union catalog staff locates eight thousand titles a year, makes bibliographies, checks bibliographies, files annually forty thousand additions, and takes care of seven thousand withdrawals. The staff that accomplishes this is composed of one trained librarian twenty hours each week, two assistants, nonprofessional and paid hourly, giving about sixteen hours each month, and four volunteers, cultivated and educated women, nonprofessional however. Besides this detail, there is time for much discussion of local library prob- lems-and some of the state and nation.

I do not pass lightly over those seven thousand withdrawals which come from the ever-growing libraries that must discard as they purchase. Small libraries in Westchester are composed largely of gifts from the families of the neighborhood as the great houses are abandoned and private libraries dispersed. Many of the books are rare and out-of-print, but valuable, if got into the right library, a larger one or a depository, to satisfy the research of the many scholars moving into Westchester County. This situation has been considered from every point of view for several years and rare enough titles redeemed from sale or destruction. It is fortifying to have George Macaulay Trevelyan, in his I945 lecture to the Book League, speak of the passing of the private library in England and the disappearance of "standard histories and biographies of ten, thirty, or one hundred years ago." The present acute shortage may be gradually remedied and many old titles republished. But if communities which have an intellectual heritage do what they can at once to preserve the variety of valuable old books what a gain will have been made! A depository in Westchester County is possible, with many books in storage, but the fulfilled plan with every detail perfect, is not, at the moment, predictable.-Katherine Tappert Willis, librarian, Westchester Library Association Union Catalog.

\section{The Union Catalog of the Library of Congress}

$\mathrm{T}$ HE FOUNDATION of the National Union Catalog was laid in 1901 when the $\mathrm{Li}$ brary of Congress began to exchange its printed cards for cards being printed by other American libraries. The pioneer cooperators were Boston Public, New York Public, John Crerar, Newberry, Harvard, and the libraries of Illinois and Chicago universities. As other libraries began to print cards, they too were brought into the exchange agreement.

During 1926 the late E. C. Richardson, then consultant in research and bibliography at the Library of Congress, who headed up a concerted drive for closer library cooperation particularly through expansion of the union catalog, succeeded in obtaining from John D.
Rockefeller, Jr., a gift of $\$ 250,000$ to be administered as Project "B" of the Library of Congress on a budget of $\$ 50,000$ annually for the period 1927-32. The administration of this project was given to the late Ernest Kletsch under the general direction of Dr. Richardson.

A full statement on the historical background of this period may be found in R. B. Downs's Union Catalogs in the United States. It will suffice here to state that, by necessity, the basic philosophy of the administrators of Project "B" was to list in the union catalog as many books as possible in as many libraries as possible, without regard to the consideration of complete coverage of any library. 
During the tenure of the project, $6,300,000$ cards were added to the catalog, bringing its total number of cards in 1932 to more than $8,300,000$. In addition, Project " $\mathrm{B}$ " was responsible for the establishment of an index to special collections in American libraries, separate Slavic and Hebraic union catalogs, and other special lists, such as lists of festschriften, photofacsimiles, etc.

The principal additions made to the main union catalog by Project "B" were: a complete set of author entry Library of Congress printed cards; more than a million temporary entries and cross references copied from the various catalogs of the Library of Congress; three-quarters of a million cards copied from the Harvard College Library catalog; a quarter of a million cards copied from the Princeton University Library Catalog; and the clipping and pasting of a million and onequarter entries from more than one hundred book catalogs, including all volumes of the Index Catalogue of the Library of the Surgeon-General's Office.

The present Union Catalog Division was created in 1932 when the Congress made its initial appropriation of $\$ 20,000$ for the purpose. From 1932 through June 1943 these annual appropriations averaged less than onehalf the sum available under the Rockefeller grant. Since July 1943, however, the division has received appreciably increased appropriations, our current budget being $\$ 53,266$ and that for the fiscal year commencing July I being $\$ 86,200$. From eleven positions in 1933 , the staff has grown to twenty-one regular positions at the present time and, as a result of the increased appropriation for the next fiscal year, we shall have an even larger staff after July I, 1946.

The primary responsibilities of the division are to maintain the various union catalogs and special lists, including the checklist of certain periodicals, and to supply inquirers with information on the location of titles. Of course, the bulk of all activity is in connection with the National Union Catalog of Books in American Libraries. During the past twelve months more than 317,000 cards, including Library of Congress printed cards, were received for this catalog, not including 130,000 cards typed by the staff from the Philadelphia and Cleveland union catalogs or cross-references and clipped and pasted cards prepared by the staff. In addition, the staff checked against the National Union Catalog, a total of 500,000 cards from the Philadelphia and Cleveland union catalogs, trays of which were sent to $\mathrm{W}$ ashington for the purpose. In this operation locations of books shown by these catalogs were recorded in the National Union Catalog.

During the past twelve months the division was called on to search a total of 9,600 titles in the union catalog, for which locations were found for 66 per cent. During the past twelve months 830,000 cards were alphabetized and filed into the union catalog. Also during the past twelve months a good start has been made on the terrific problem of editing the main catalog. Only one staff member is assigned to this duty and only those areas of the catalog which cry for attention receive it. Nevertheless, a technique is being learned and a corpus of rules is being established which should aid future editors greatly. The above statistics refer to the main union cata$\log$ only.

A considerable amount of one assistant's time was spent in maintaining the checklist of certain periodicals which records the locations, by volume and number of issue, of nearly four thousand scientific and technical periodicals published mainly in the late warring countries, 1939-45. The master file is being kept up-to-date with information supplied by cooperating libraries. The burden of servicing inquiries concerning periodicals listed in the checklist has diminished greatly since the publication of a limited edition of the list slightly more than a year ago. Even so, nearly one thousand searches were made in it by the staff for inquirers outside of Washington.

Other activities which should be mentioned briefly are:

I. The American Imprints Inventory.

2. The preparation of lists of author headings under Great Britain and United States.

3. The union catalog of negative microfilms of newspapers.

4. Cooperating library program for checking Catalog of Books Represented by Library of Congress Cards.

5. Plans for expansion of the union catalog.

The American Imprints Inventory, on three by five library slips, was turned over to the Library of Congress by the Historical Rec- 
ords Survey and the inventory is now in the custody of the Union Catalog Division. A proposed five-year budget totaling some $\$ 300,000$ for editing the inventory was only meagerly supported by the Congress, but we will be able to begin the work on a small scale on July I. Meanwhile, the material is available to qualified scholars or persons who wish to edit and publish sections of the file. For instance, a list of Amherst, Mass., imprints has recently been edited by Newton McKeon and published by Amherst College Library, and John Cook Wyllie is setting up a program to edit and publish a list of all Virginia imprints through 1875 .

The lists of Great Britain and United States (2nd edition) author headings, compiled in the division, are samples of the kind of work an enlarged union catalog staff could do to the mutual advantage of the division and the librarians and library users of the nation. These lists were originally compiled as filing guides for union catalog filers, but because of their usefulness to catalog users in ascertaining correct entries for United States and British documents as well as to librarians for use as filing guides, they were published in appropriate volumes of the Catalog of Books Represented by Library of Congress Printed Cards at the request of the A.R.L. committee for the publication of that catalog. J. W. Edwards, publisher, has generously agreed to supply the Library of Congress with five hundred reprints of each list for free distribution through the library's Information and Publications Office. It is planned that the division will compile, from time to time, similar lists of the catalog headings for publications of other countries.

With respect to the listing of microfilms, the union catalog policy is not to maintain a separate catalog of microfilms as microfilms per se. Besides, the Philadelphia Bibliographical Center already maintains and publishes its Union List of Microfilms for those who wish to know what has been microfilmed. However, the Union Catalog Division does maintain a special list of microfilm negatives of newspapers and other materials in signifi- cant runs to serve as the basis for cooperative microfilming projects and to prevent the expenditure of appreciable sums of money on repetitious microfilming undertakings. It is hoped that a new edition of the Preliminary Checklist of Newspapers on Microfilm can be published after forms now in preparation are distributed to and returned by cooperating libraries.

The program sponsored several years ago by the A.R.L. Committee on the Union Cata$\log$, under which some fifty libraries agreed to check their catalogs against the Catalog of Books Represented by Library of Congress Printed Cards and report to the union catalog titles for which no Library of Congress card was printed, has yielded to date a total of 260,000 cards. This figure is far smaller than we had expected but it is thoroughly understood that the consequences of the war and not lack of interest on the part of librarians is responsible. The point I wish to emphasize here is that in principle the project is a sound one and, if carried to completion, will add to the union catalog a million or more net new titles which otherwise would probably never be recorded so thoroughly. Approximately 50 per cent of all such titles submitted to date are new to the union catalog.

Of course, the future development of the union catalog depends principally on the extent to which the Congress agrees with our recommendations. Our request to the Congress for additional funds for two five-year projects, one to edit the American Imprints Inventory, the other to check nine regional union catalogs (other than those at Cleveland and Philadelphia which are now being checked on a five-year project) and thirty-seven research library catalogs into the National Union Catalog, resulted in the granting of an additional $\$ 32,000$ for the next fiscal year. This additional money will be used to carry the development of the catalog as far as possible down the line suggested in our justifications for the additional $\$ 180,000$ originally requested.-George A. Schwegmann, Jr., director, Union Catalog and Photoduplication Service, Library of Congress. 


\section{Union Catalogs of Southeastern Michigan}

W HEN the union catalogs of Southeastern Michigan were first discussed, there was in existence no union catalog showing holdings of Michigan libraries. The union catalog at the University of Michigan Library at that time was a Library of Congress depository catalog (then the only one in the state) to which printed cards from other libraries, such as the John Crerar Library and the Harvard University Library, had been added. When the publication of $A$ Catalog of Books Represented by Library of Congress Printed Cards was announced and the Detroit Public Library was made a depository library in $\mathbf{1 9 4 2}$, tentative plans were made to start two projects: one to begin a union catalog in the Detroit Public Library, the other to add the reported holdings to the University of Michigan Union Catalog.

These plans materialized in February 1943, the date the first volumes of the Library of Congress printed catalog were received. As you know, the Library of Congress catalog reproduces the complete series of Library of Congress cards through July 31, 1942. The union catalog in Detroit is based on this catalog supplemented by a card file composed of the Library of Congress depository cards since Aug. I, 1942, combined with typed cards from the contributing libraries. Originally there were six contributing libraries in the area: Michigan State Library in Lansing, Michigan State College in East Lansing, University of Michigan in Ann Arbor, and, in Detroit, University of Detroit, Wayne University, and the Detroit Public Library. Later in the year the Cranbrook Academy of Art Library in Bloomfield Hills, near Detroit, joined the group.

All of the contributing libraries except the University of Michigan report their holdings to Detroit by checking their copies of the Library of Congress catalog. Each library indicates in the margin of the printed entry the titles represented in its collection, if the Library of Congress card fits the book exactly or varies only in one item. One variation is indicated by a penciled note, as $\mathrm{MiD}=1924$, if the Library of Congress date is 1923. When the volume is completely checked a form post card is sent to Detroit, and this library notifies the contributing library when to send in the completed volume. Up to the present time we have been ready to work on the volumes as soon as they have been checked, but this formality is a precaution against receiving several at one time and so depriving the contributing library of the use of its volume longer than necessary. Green was chosen as the most satisfactory color for ink used in stamping, since it produces a clear stamp and is not tiring to the eyes. When the stamping is completed in the Detroit volume, that copy is then sent to the University of Michigan Library where all the holdings indicated in the Detroit volume are added to the cards in the union catalog and the University of Michigan holdings are stamped in the Detroit copy. This completes the records in both union catalogs.

Current cataloging using Library of Congress cards in that part of the alphabet which has already been checked is reported to the union catalogs by a brief entry on a three by five slip. This carries only enough information to identify the Library of Congress card (full entry, first word of the title, card serial number) and the name of the contributing library. The routine outlined above covers only titles for which Library of Congress cards have been printed. As the volumes are checked, entries in each contributing library which are not represented by a printed card are duplicated for the union catalogs and cross references not in the Library of Congress catalog are also included. The same method is followed in current cataloging. If the entry files within the section already checked, typed cards are made if no Library of Congress card has been printed. These cards are made in a simplified form, using only a short title, brief imprint and collation, and omitting all notes except series, bibliography, and source. The full entry in Library of Congress form is necessary for filing.

Certain types of material have been omitted from the union catalogs. At present these are: serials, with the exception of monograph series and publications of Michigan organizations; newspapers; U.S. documents; state and local documents; phonograph records; college catalogs; manuscripts (including theses); 
analytics for parts of volumes except for complete items not otherwise represented in the library; and maps. In addition to reporting items in, and being added to, the collections of the contributing libraries, withdrawals in the sections which have been reported to the union catalogs are reported on cards or slips.

The technique of checking and reporting has worked very satisfactorily. However, for reasons which are familiar to all librarians, chiefly lack of time and personnel during the war years, progress has been slow. On May I, 1946, the checking ranged from Volume 7 to Volume 64 ; seven volumes are completed and Detroit holdings have been stamped in sixty-four. The supplementary card file has grown rapidly. Between August 1942 and May 1946 we have received nearly 304,000 Library of Congress cards, greatly exceeding the original estimate of 50,000 depository cards per year. Added to this file have been approximately 36,500 cards from the contributing libraries. In the same period Detroit has sent over 8,000 cards to the University of Michigan. The University of Michigan has checked 102 trays of its III3-tray official catalog for titles cataloged without Library of Congress cards and has sent a copy of its own printed card or a typed card to Detroit. Esther A. Smith, the head of the catalog department, reports that 832 hours, including searching and typing time, were spent in completing the work on roo trays. The time spent in checking entries in a Library of Congress volume varies considerably: Ann Arbor reports $3 \frac{1}{2}$ to 15 hours per volume; Detroit more than double that amount. One reason for the longer period is that checking in Detroit has to be done with the main public catalog, since the official catalog is not a complete record for the library. Another reason is that it has been necessary in Detroit to write brief "dummy" cards for items already cataloged which should be copied for the University of Michigan Union Catalog, because checking time was available but typists were not. This typing is much in arrears at present, although union catalog records for current titles are made as the items are cataloged.

When the checking was begun in Detroit two cards were typed for each item not represented by Library of Congress cards. One was sent to the University of Michigan, the other added to the supplementary card file of the Detroit Union Catalog. Later it was decided that this-was unnecessary duplication since the union catalog and the public catalog (the complete catalog for the main library) are and will remain in the same room. The Detroit Public Library cards were withdrawn from the union catalog supplementary card file and sent to the National Union Catalog at the Library of Congress, and Detroit has continued this practice in its current cataloging.-Frances, M. McDonald, chief, Catalog Department, Detroit Public Library.

\section{Summary}

T I94I-42, when the A.L.A. Board on 1 Resources of American Libraries sponsored a national survey of union catalogs and bibliographical centers, financial questions were uppermost. It is apparent from the preceding papers that budgets are still a major problem. The most encouraging feature of the bibliographical center situation today, however, and the most convincing argument for continuing the centers, are that cooperating libraries are willing to contribute to their support. When one considers the limited funds with which many of the libraries operate, they could pay no more perfect tribute to the effectiveness and value of bibliographical center services.

Methods of establishing financial contributions from individual libraries differ from one center to another. At Seattle, especially, the system seems to be fairly exact, with each library in the region knowing precisely what is expected of it.

Another point of striking interest is the great variety of services performed by bibliographical centers. They have gone 
far beyond the old passive role of locating books, characteristic of most union catalogs. Of course the location function is still fundamental, but the centers are now branching out in such directions as facilitating interlibrary loans, guiding acquisition activities, improving cataloging processes, and preparing subject catalogs and bibliographies. The Philadelphia center, in particular, is developing a range of activities probably not even visualized by union catalog pioneers. In part, this variety is made possible by the Philadelphia center's location in a large urban area, rich in library resources. As a matter of fact, each center differs in administration, organization, and services because of the diverse need of the several clienteles and regions.

A service mentioned in connection with the Philadelphia center seems to me unusually significant, namely, the plan of directing inquiries to libraries best equipped to supply requested information. Such an arrangement makes complete centralization unnecessary and yet effectively mobilizes information sources. The idea might be broadened to include individuals and any other community resources useful for data purposes.

One might assume that the services offered by such an agency as a bibliographical center would be chiefly of interest to scholars. Figures cited by the participants in this symposium demonstrate, on the contrary, that almost every element in the community-teachers, students, businessmen, government workers, and many others -make use of the existing centers.

It is clear from material presented in the papers that considerable advantages for bibliographical centers come from locations in university or other libraries with strong reference and research facilities. Instead of starting from scratch, the centers under these conditions begin with book and staff resources that would otherwise require years to build up.

Mr. Schwegmann's report on the rapid expansion of the National Union Catalog and its increasingly generous support from Congress is highly encouraging. It is of special importance that appropriations have been made to check into the union catalog at the Library of Congress the records of holdings in the Philadelphia, Cleveland, and other regional union catalogs. From the point of view of the country as a whole, it will unquestionably be more useful to have this information centralized in Washington than widely scattered among many different catalogs. Mr. Schwegmann's statement also reveals that the National Union Catalog is developing a variety of new projects and services, expanding its scope and value.-Robert Bingham Downs, director of libraries, University of Illinois. 


\section{REPORT OF THE COMMITTEE ON BUILDINGS AND ARCHITECTURE FOR THE W.AR YEARS}

$\mathrm{D}$ URING THE WAR YEARS the A.C.R.L. Buildings and Architecture Committee has done two things: first, it has tried to answer specific questions addressed to it; and second, it has tried to evolve a sound policy to follow in the future.

What we have learned during the war years leads us to offer certain observations, which, in turn, are the foundation of the policy the committee has followed recently.

First, seldom does a librarian have an opportunity to plan more than one building. This means that there are no real building experts within the proféssion and that there is very little cumulative wisdom brought to bear on proposed buildings. Almost everyone starts from scratch and almost everyone makes the same mistakes that have been made before.

Second, most librarians don't seem to get around much to study at first hand the new buildings that might be worth studying. Eastern librarians, especially, seem terrified by the idea of looking west of Chicago. Westerners are less timid. There are exceptions.

Third, librarians seem to have little instinctive or acquired knowledge of how to go about organizing a building program. Too often they seem unable to analyze the needs of their institution or to write these needs into a definite program that can be understood and acted upon by the architect.

Fourth, librarians become bewitched by the jargon of the day. The right words are often used in the program-such as flexibility, nonmonumental, expansible, unified, correctly proportioned, etc.-but these words are seldom realistically incorporated into the building. It seems that we librarians don't know the true meaning of the terms we use.

Fifth, in many cases, the librarian, when faced with the prospect of a new building, becomes panicky and writes to the A.L.A. for a reading list and a collection of pictures and blueprints-as a substitute for settling down and doing his own reference work and analysis.

Sixth, it is seldom taken into consideration that there will be an architect for every building program and that the architect is likely to be a great deal more intelligent, up-to-date, and reasonable than librarians ordinarily think. Our well-known difficulties with our architects arise, too often, because we librarians are not able to analyze and state our program properly, because we change our minds too often, and because we act as though we know more about the architect's business than he does. Of course, there have been, and are, architects who are prima donnas and who are liable to run away with any project they get their hands on. These cases appear to be the exception, not the rule.

Architects live on the profits they make when they design buildings. If, in the development of a library project, we librarians can't make up our minds as to what we want and thereby force the architect to do innumerable revisions of the plans, we wipe out his profits. And when the architect sees that this is happening to him, he, naturally, tries to take matters into his own hands.

Seventh, librarians are too prone to try to reproduce existing buildings-mistakes and all. There are very few distinctive and original college and university libraries in the United States.

Eighth, any librarian who has planned one building tends to be accepted as an authority by his colleagues, no matter how much or how little he knows.

Ninth, we still labor under the illusion that a library is a library, and that a man who knows something about public library buildings automatically is also an authority on college and university libraries, and vice versa. It isn't true.

Tenth, many librarians expect the A.L.A. to set up a clinical service to which they can turn for the solution of their problems.

These, and other considerations have held the committee to adopt a procedure to be used from now on out.

But before outlining the new procedure, a few words should be said about what the committee has done the last two years. It 


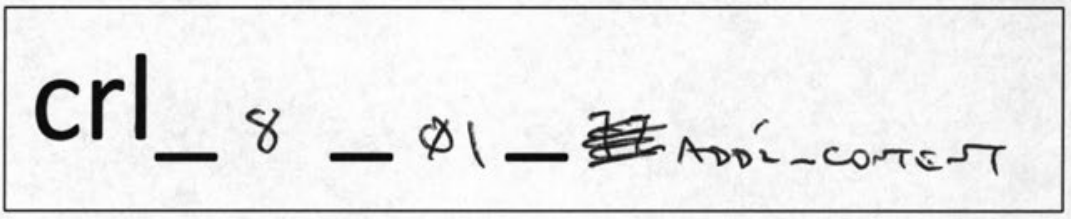



$-$ 
has tried to answer specific questions as well as it could, and there have been many of these. It has seen to it that new building methods-such as modular planning-are written up, and that new ideas on library organization are discussed. These reports are to be found in recent issues of the Journal of Higher Education, Library Journal, College and Research Libraries, and the American School and University Yearbook. The committee has also cooperated with the Committee on Cooperative Building Projects organized by Julian P. Boyd. The contributions of the cooperative committee will soon be made available to the profession.

The committee has not distributed reading lists because that seems unnecessary and foolish. If librarians, of all people, can't dig out their own literature, they should quietly fold up their tents and go away.

\section{New Procedure}

We have come to see that our practice of answering questions by correspondence, by members of the committee, is, in the long run, a disservice to the profession. From now on we intend to urge librarians faced with a building program to call in a library consultant who will be capable of making a careful and thorough survey of the college or university's needs and problems and also capable of assisting in the writing of the program before it is given to the architect for execution.

We have come to consider the survey and the written program the critical points in proper library planning. And we believe that this work cannot be done by correspondence or through reading lists or by any central clinic. We think it important that a consultant go directly to the campus and study its problems on the ground. The consultant can be expected to review the final preliminary plan, but normally the preparation of the plans should be left in the hands of the architect and the librarian. The principal job of the consultant is to help in the forma- tion of a well-thought-out and clearly stated program.

We expect to state clearly that such surveys cost money and that the services of a consultant are not free. But we shall also try to show that the cost of a survey is sure to be saved many fold. We know from actual experience that most college and university presidents will be quick to see the wisdom of having a survey made. Our task is to convince the librarian of the necessity of taking this step.

The committee will be prepared to list consultants who, in the judgment of the committee, are capable of doing the work. The committee will begin to concentrate its energies on the "education" of consultants.

The A.L.A. Headquarters Library will continue to do the job of collecting pictures and plans for the use of the profession. But it will channel requests for help and information directly to the committee.

The committee will, of course, be glad to assist in the finding of answers to spot questions of a specific nature, where the services of a consultant would not be relevant.

The committee is not in favor of the idea of establishing a buildings clinic at A.L.A. Headquarters, because it does not believe that such a clinic, no matter how well-supported financially, can materially assist in the truly important part of library planning; namely, the development and statement of the program. If money is to be available to finance such a clinic, the committee would prefer to have the use of this money in its program of developing competent consultants.

Inquiries should be addressed to the new chairman, William H. Jesse, librarian, University of Tennessee Library, Knoxville.

William H. Jesse

EdNa Ruth Hanley

Blanche Prichard McCrum

JoHN E. BURChard

Edward A. Henry

Richard H. Logsdon

RALPH E. ELLSWORTH 